\title{
FIELD PEA PISUM SATIVUM L. AS A PERSPECTIVE INGREDIENT FOR VEGAN FOODS: A REVIEW
}

\author{
*Ieva Rasskazova, Asnate Kirse-Ozolina \\ Latvia University of Life Sciences and Technologies, Latvia \\ *Corresponding author's email: ievanr9@inbox.lv
}

\begin{abstract}
Dry seeds of peas (Pisum sativum L.) have long been used as a staple food and feed globally, and its nutritional, health and ecological benefits comply with growing demand for novel vegan foods intended for health and sustainability conscious individuals. The aim of this study was to review research findings and latest information on field pea usage as a functional ingredient in vegan foods. Monographic method was used to analyse field pea Pisum sativum L. usage as a diverse and multifunctional ingredient in vegan foods, covering latest available information on chemical composition of field pea and main food ingredients made from field pea, focusing on the varieties from which yellow split pea is produced; their impact on ready product's nutrition, sensory properties and application in food industry. Major types of novel vegan foods containing field peas available on market were named. Pea protein, starch and fibre have demonstrated functional properties in different food systems, including - emulsification, oil-in-water system stabilisation, texture modification, binding, gelation, foaming, and solubility. It is functionally possible and nutritionally and ecologically desirable to develop novel vegan foods intended as animal product alternatives with acceptable sensory properties.
\end{abstract}

Key words: plant protein, vegan food, functional properties, novel food, field pea.

\section{Introduction}

Peas, more specifically the yellow or green cotyledon varieties known as dry, smooth or field peas, are the naturally dried seeds of Pisum sativum L. and are grown around the world (in temperate and subtropical climate) (Dahl, Foster, \& Tyler, 2012).

Cultural traditions have a strong influence on the type of peas grown and consumed in different regions and countries (Rawal et al., 2019). Peas are also grown in Latvia - for human consumption, also animal feed and as a rotational crop for cereals to gain crop's higher energetic productivity (Kirse \& Karklina, 2014; Osmane et al., 2016). Pea landraces and varieties exhibit diversity of forms and growing types, adapted to diverse environments, cropping systems, and end-uses (as food, feed, or fodder) (Tayeh et al., 2015). Latvian citizens usually consume green/ garden peas (Pisum sativum L.), chickpeas (Cicer arietinum L.), maple peas (Pisum sativum L. var. arvense) and yellow split peas (Pisum sativum L.) (Kirse \& Karklina, 2014). The vast majority of the world's production of peas are yellow field peas, followed by green field peas and a few other types produced only in smaller quantities. World production of dry peas in 2018 was more than 13.5 million tonnes, the major producers being Canada, Russia and China; Latvia produced 22500 tonnes of dry peas per year (FAOSTAT, 2020). Uniquely, when comparing with other legumes, in the developed countries dry pea production is driven by demand for animal feed and not for human consumption (Bansal \& Bansal, 2019).

Peas being a legume crop have two aspects that distinguish them from most other food crops. Firstly, they are rich with macro and micronutrients: being a good source of protein (rich with essential amino acids as tryptophan and lysine), slowly digestible carbohydrates, B group vitamins, minerals, dietary fibre (soluble and insoluble), phytosterols, $\alpha$-linolenic acid; they also provide some amounts of squalene, tocopherols, polyphenols and triterpenic acids (Kalogeropoulos et al., 2010; Rawal et al., 2019; Roy, Boye, \& Simpson, 2010).

Secondly, peas, like other plants of the Leguminosae family, take part in maintaining the environmental sustainability of agriculture with a process of biological nitrogen fixation. Pea crop in symbiosis with soil-borne rhizobia bacteria forms root nodules which absorb inert nitrogen from soil and air, and convert it into biologically useful ammonia, part of which is released into the soil. Consequently, the pulse crops do not need any additional nitrogen as fertilizer and the requirement of nitrogen fertilization in crops that follow in the cropping cycle is also reduced (Tayeh et al., 2015).

Dry seeds of peas have long been used as a staple food and decreases symptoms of such with diet-related diseases as obesity, diabetes, heart diseases, also demonstrates positive influence in the prevention of various forms of cancer (Michaels, 2016). This effect has been directly linked to their chemical content and low glycaemic index, also with traditional usage as an alternative to animal protein in vegan and vegetarian diets (Rohn \& van Griensven, 2015).

In general there is growing awareness of health and ecological benefits when choosing vegetarian, vegan or semi-vegetarian diet (Van Dooren et al., 2014). The global market for plant-based products continues to grow, which creates demand for ingredients that comply with vegetarian and vegan dietary needs, especially more protein from ecologically sustainable sources. Global availability, nutritional, health and 
ecological benefits makes field pea uniquely qualified as a source of new vegan foods.

The aim of this study was to review research findings and latest information on field pea's usage as a functional ingredient in vegan foods.

\section{Materials and Methods}

To analyse and summarise the latest information published in scientific journals on field pea's Pisum sativum L. composition, nutritional and health benefits, functional properties and functional ingredients acquired from its edible seeds for use in food industry, the monographic method was used. In order to compile information on some commercially available novel vegan foods made with pea ingredients, Internet resources were used.

\section{Results and Discussion}

Chemical composition, nutritional and health benefits of field pea

Approximate chemical content of pea Pisum sativum L. has recently been compiled by Dahl, Foster, \& Tyler (2012). Whole pea seed contains: protein $21.2-32.9 \%$ of dry matter (DM), starch $36.9-49.0 \%$ DM, resistant starch 2.1-6.3\% DM, amylose 20.7$33.7 \%$ of total starch, total dietary fibre $14-26 \% \mathrm{DM}$ (including insoluble fibre $10-15 \% \mathrm{DM}$ and soluble fibre $2-9 \% \mathrm{DM}$ ), soluble sugars $5.3-8.7 \% \mathrm{DM}$, total lipid 1.2-2.4\% DM, ash 2.3-3.4\% DM (Dahl, Foster, \& Tyler, 2012). Field pea's chemical composition demonstrates which functional ingredient groups could be extracted from pea. Table 1 provides the overview of major functional properties associated with pea and specific pea fractions.

Peas are a valuable source of protein for human and animal diet. Pea protein content is influenced by pea seed maturity, environmental and genetic factors (Roy, Boye, \& Simpson, 2010). It is approximately $22.5 \%$
(18.59-26.37\%) of dry matter in various pea varieties grown in Latvia (Osmane et al., 2016), which makes it comparable with meat protein content. Although pea protein is not complete dietary protein (in comparison to meat, poultry, fish, dairy, eggs and soya (Glycine $\max$ ) protein) with limiting amount of essential amino acids - methionine and tryptophan, it is good source of lysine (De Almeida Costa et al., 2006). KruminaZemture, Beitane and Gramatina (2016) established

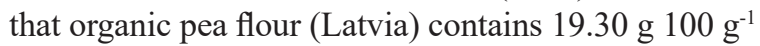
of total amino acids, from which approximately $35 \%$ $\left(6.89 \mathrm{~g} \cdot 100 \mathrm{~g}^{-1}\right)$ was essential amino acids, from which $22 \%$ was lysine $\left(1.58 \mathrm{~g} \cdot 100 \mathrm{~g}^{-1}\right)$. It is advised to include peas in plant based vegetarian and vegan diet together with other legumes and cereals to improve total dietary protein's adequacy (Kirse \& Karklina, 2014).

Dry seeds of peas (and other pulses) rank below foods of animal origin but above other plant-based foods in terms of protein quality due to the presence of anti-nutritional factors such as phytates, protease inhibitors and lectins (Boye, Zare, \& Pletch, 2010). In vitro digestibility of raw pea protein is reduced, although the digestibility of isolated pea protein has been reported to be higher than that of soybean and several other pulses (Osmane et al., 2016; Yang et al., 2012).

At the same time lectins and bioactive peptides have demonstrated bioactive properties: they exert anticancer, immunomodulatory properties and a variety of bioactivities in vitro, including angiotensin I-converting enzyme inhibitor activity with antihypertensive effect and antioxidant activity, accordingly (Roy, Boye, \& Simpson, 2010).

Starch and fibre are other major components of pea seed DM (Dahl, Foster, \& Tyler, 2012). In peas 18.2$23.8 \%$ of starch is rapidly digestible starch (RDS), slowly digestible starch (SDS) is 53.7-59.0\% and resistant starch (RS) content is $8.1-12.6 \%$ (Hoover

Major functional properties associated with pea and specific pea fractions in novel food systems

Table 1

\begin{tabular}{|c|c|c|}
\hline $\begin{array}{l}\text { Pea fraction, } \\
\% \mathrm{DM}^{\mathrm{a}}\end{array}$ & Functional properties in final product & Reference \\
\hline $\begin{array}{l}\text { Protein, } \\
21.2-32.9 \%\end{array}$ & $\begin{array}{l}\text { - fat/ water binding, allowing adequate texture, emulsification, and gelation, } \\
\text { - solubility, emulsifying stability and foaming properties, } \\
\text { - good emulsification properties and emulsion stability upon heat and freeze-thaw } \\
\text { treatments, }\end{array}$ & $\begin{array}{l}\text { Geerts et al., } \\
2017 \text {, } \\
\text { Lan } \text { et al., } \\
2019\end{array}$ \\
\hline $\begin{array}{l}\text { Starch, } \\
36.9-49.0 \%\end{array}$ & $\begin{array}{l}\text { - as a binder in food systems, } \\
\text { - as texture modifying agents, }\end{array}$ & $\begin{array}{l}\text { Pietrasik et } \\
\text { al., } 2020\end{array}$ \\
\hline $\begin{array}{l}\text { Dietary fibre } \\
14-26 \%\end{array}$ & $\begin{array}{l}\text { - as a filler in food systems, } \\
\text { - as texture modifying agents, } \\
\text { - good stabilizing properties at acid condition, }\end{array}$ & $\begin{array}{l}\text { Pietrasik et } \\
\text { al., 2020, } \\
\text { Cheng et al., } \\
2018\end{array}$ \\
\hline
\end{tabular}

a - \% DM - chemical component's amount in whole seed, \% from dry matter (DM), information compiled by Dahl, Foster, \& Tyler, (2012); 
Novel vegan foods made with field peas Pisum sativum $\mathbf{L}$.

\begin{tabular}{|c|c|c|c|}
\hline Product & Pea derived ingredient & $\begin{array}{l}\text { Protein, } g \cdot 100^{-1} \mathrm{~g} \\
\qquad\left(\mathrm{gPS}^{\mathrm{a}}\right)\end{array}$ & Producer (source) ${ }^{\mathrm{b}}$ \\
\hline Cooked yellow split peas & split pea $^{\mathrm{c}}$ & $10(13)$ & Kalogeropoulos et al., (2010), Greece \\
\hline \multirow{2}{*}{$100 \%$ pea protein powder } & \multirow{2}{*}{ PPI } & $80(20)$ & IronMaxx, Germany (IronMaxx.de) \\
\hline & & $77(23)$ & Prozis, Portugal (Prozis.com) \\
\hline $\begin{array}{l}\text { VEGANMASS - mass } \\
\text { gainer powder }\end{array}$ & PPI, pea starch & $39(30)$ & $\begin{array}{l}\text { Vegun Nutrition, USA } \\
\text { (VegunNutrition.com) }\end{array}$ \\
\hline \multirow{3}{*}{ MF burger } & PPI & $18(20)$ & Beyond Meat, USA (BeyondMeat.com) \\
\hline & $\begin{array}{l}\text { rehydrated textured } \\
\text { PPI, PF, pea fibre }\end{array}$ & $14(14)$ & CIglo, Germany (Iglo.de) \\
\hline & PP (with soya protein) & $22(22)$ & $\begin{array}{l}\text { The Meatless Farm, UK } \\
\text { (meatlessfarm.com) }\end{array}$ \\
\hline MF meatballs & $\begin{array}{l}\text { rehydrated textured } \\
\text { PPI, PF, pea fibre }\end{array}$ & $16(16)$ & Birds Eye, Ireland (BirdsEye.ie) \\
\hline MF minced meat & PPI & $18(20)$ & Beyond Meat, USA (BeyondMeat.com) \\
\hline MF sausage preparation mix & PP (with chickpea PF) & No information & SIA Gardais, Latvia (Gardais.lv) \\
\hline MF sausages & $\begin{array}{l}\text { rehydrated } \mathrm{PP}, \mathrm{PF} \text {, pea } \\
\text { fibre }\end{array}$ & $16(16)$ & Birds Eye, UK (BirdsEye.co.uk) \\
\hline DA drink & PP & $3(8)$ & Qwrkee, UK (Qwrkee.com) \\
\hline DA drink & PP & $3(8)$ & Ripple Foods, USA (RippleFoods.com) \\
\hline DA drink & PPI & $3(8)$ & SIA "Nature Foods", Latvia (Happea.com) \\
\hline $\begin{array}{l}\text { Creamy Yogurt Alternative, } \\
150 \mathrm{~g}\end{array}$ & PP & $4(6)$ & Ripple Foods, USA (RippleFoods.com) \\
\hline $\begin{array}{l}\text { Pea \& Pinto Bean Sticks, } \\
100 \mathrm{~g}\end{array}$ & green $\mathrm{PF}$ & $9(3)$ & $\begin{array}{l}\text { Off The Eaten Path Australia } \\
\text { (OffTheEatenPathSnacks.com.au) }\end{array}$ \\
\hline $\begin{array}{l}\text { Probiotic Vegan Cheese } \\
\text { Puffs } 80 \mathrm{~g}\end{array}$ & PF & $20(4)$ & Qwrkee, UK (Qwrkee.com) \\
\hline Protein bar, $75 \mathrm{~g}$ & PP & $29(22)$ & $\begin{array}{l}\text { Organic Food Bar, USA } \\
\text { (OrganicFoodBar.com) }\end{array}$ \\
\hline
\end{tabular}

${ }^{\mathrm{a}}-\mathrm{g}$, PS - g per serving, according to producer's information; ${ }^{\mathrm{b}}$ - web pages retrieved on March, 8, 2020; specific source information will be sent after individual request to author; ${ }^{\mathrm{c}}$ - boiled for $30 \mathrm{~min}$ and then left in colander for 5 min for drainage; $\mathrm{MF}$ - meat free, $\mathrm{DA}$ - dairy alternative, $\mathrm{PP}$ - pea protein, $\mathrm{PPI}$ - pea protein isolate, $\mathrm{PF}$ - pea flour.

et al., 2010). The properties of pea starch and fibre constituents make peas a low-glycaemic index food, which increases insulin response stability due to a decrease in blood glucose fluctuation after slower glucose release, which can help in the prevention and management of obesity, high blood cholesterol and type 2 diabetes (Dahl, Foster, \& Tyler, 2012; $\mathrm{Lu}$, Donner, \& Liu, 2018). Major minerals in pea are $\mathrm{K}$ (1040 $\mathrm{mg} \cdot 100 \mathrm{~g}^{-1}$ of dry, dehulled weight), $\mathrm{P}$ (390 mg·100 g $\left.\mathrm{g}^{-1}\right), \mathrm{Mg}\left(100 \mathrm{mg} \cdot 100 \mathrm{~g}^{-1}\right)$ and $\mathrm{Ca}$ $\left(80 \mathrm{mg} \cdot 100 \mathrm{~g}^{-1}\right)$. From trace minerals on average pea contains Fe $\left(9.7 \mathrm{mg} \cdot 100 \mathrm{~g}^{-1}\right)$, Se $\left(4.2 \mathrm{mg} \cdot 100 \mathrm{~g}^{-1}\right)$, $\mathrm{Zn}$ (4.1 mg·100 $\left.\mathrm{g}^{-1}\right)$, Mo (1.2 mg·100 $\left.\mathrm{g}^{-1}\right)$, Mn $\left(1.1 \mathrm{mg} \cdot 100 \mathrm{~g}^{-1}\right)$ and $\mathrm{Cu}\left(0.9 \mathrm{mg} \cdot 100 \mathrm{~g}^{-1}\right)$. Pea contains folate in various amount from $23.7 \mu \mathrm{g} \cdot 100 \mathrm{~g}^{-1}$ to $101.0 \mu \mathrm{g} \cdot 100 \mathrm{~g}^{-1}$ (Dahl, Foster, \& Tyler, 2012). Pea minerals bioavailability is poor due to high phytate concentrations. Phytate degradation could make peas as a significant source of $\mathrm{Ca}, \mathrm{Zn}$ and $\mathrm{Fe}$ (Dahl, Foster, \& Tyler, 2012). Pea flour (Latvia) was observed to be a good source (in comparison to wheat) of vitamins $\mathrm{B}_{1}$ and $\mathrm{B}_{2}-1.11 \mathrm{mg} 100 \mathrm{~g}^{-1}$ and $0.71 \mathrm{mg} 100 \mathrm{~g}^{-1}$, respectively (Beitane \& Krumina-Zemture, 2017).

Pea application in food industry

In addition to traditional pea soups, casseroles, boiled and/or baked, roasted peas as staple food and humus made from canned, frozen or dried peas, there are many new vegan foods made with field pea or pea fractions recently launched on global food market. Some of these foods with their trade names, pea ingredient type and producer information are shown in Table 2.

Mostly dry pea flour $(<65 \%$ protein, DM), protein concentrate (PPC, $>65 \%$ protein, $\mathrm{DM}$ ) or isolate (PPI, 
$>90 \%$ protein, DM) have been used as a source of protein and/ or for maintaining other functional and sensory properties in selected food (Boye, Zare, \& Pletch, 2010).

Major novel vegan foods with pea ingredients could be categorised in such groups: meat product analogues (plant-based burgers, sausages, 'meat ball alternatives', 'minced meat alternatives' etc.), dairy product alternatives (drinks, yoghurt-like gels, cheeselike alternatives, and others, which usually have been recognised by using terms employed in dairy industry, but according to Regulation No 1308/2013 of the European Parliament and Council (Reg. 1308/2013, 2013) can't be labelled as such any more), food supplements (protein powders, emulsifiers), snacks (energy bars, extrudates), fortified cereal products (traditionally made with wheat - bread, pasta, crackers) and other.

Pea processing methods like soaking, steaming, thermal treatment, extrusion, fermentation, germination etc. affect pea chemical composition and can significantly improve pea protein digestibility and nutritional value, increase antioxidant activities (Boye, Zare, \& Pletch, 2010; Singh et al., 2017).

Most functionally researched, adapted and commercially used pea fraction is protein fraction (Table 1 and 2). Pea protein isolate main protein fractions are: salt-soluble globulin (60-80\%) with the subunits of legumin (11S) and vicillin (7S) and watersoluble albumin (2S, 15-25\%) (Shand et al., 2007).

Pea protein flour processing techniques are: air classification, alkaline extraction/ isoelectric precipitation, acid extraction, water extraction, salt extraction (micellization) and ultrafiltration (Boye, Zare, \& Pletch, 2010).

In fractionation process dried yellow peas are dehulled and ground (milled) to produce pea flour (PF). Then PF is hydrated, and the pea starch and fibre are extracted separately from protein fraction. By alkaline extraction followed by isoelectric precipitation the protein fraction is coagulated for further purification and, finally, carefully dried in a multi-stage spray dryer. This is so called wet milling process, which results in extracts with higher protein purity $(>70 \%)$ (Boye, Zare, \& Pletch, 2010; Yang et al., 2012). Also, pea starch isolate, obtained by wet milling processing is generally of higher purity (Hoover et al., 2010).

In dry milling fractionation process from $\mathrm{PF}$ through air classification process there are two separated fractions obtained: the coarser (heavier) low protein starch fraction and the lighter (finer) protein fraction. Air classification does not completely separate the protein from the starch granules and fibre, the purity of the protein fraction obtained using this process is approximately $38-65 \%$, that is why wet extraction process, ultrafiltration or isoelectric precipitation could follow (Boye, Zare, \& Pletch, 2010; Hoover et al., 2010). Air classification as dispersion/solubilization of the dehulled pea flour in water and concentration of the soluble protein after decantation of the insoluble residue (fibres and starch) followed by spray drying techniques are perceived as more sustainable process (with less use of water and chemicals) and have the advantage that protein retains its native state (Geerts et al., 2017; Moreno et al., 2020).

Manufacturing processes used to produce the protein extracts impact to different extent their functional properties (Boye, Zare, \& Pletch, 2010). With comparable nutritional and functional properties that of soya pea protein has replaced soya protein in many foods because it is perceived as being nonallergenic or non-GMO in comparison with soya (Messina \& Venter, 2020).

Though, when processed under the same conditions, pea protein isolate forms a weaker and less elastic gel than soy protein isolate (Shand et al., 2007). Shand et al. (2007) and Sun \& Arntfield (2011) demonstrated improved gelation properties of salt-extracted pea protein isolate (PPIs) through manipulation of heating temperature and heating rate, which could enhance competitiveness of PPI as functional additive.

Geerts et al. (2017) and Pelgrom, Boom, and Schutyser (2014) suggest that depending on the final application chemically less homogenous soluble pea protein fraction containing native protein conformations and small solutes, obtained through mild fractionation process could become a more sustainable and nutritional alternative for highly purified commercial ingredients with partially similar functional properties. Pea protein concentrate's emulsification properties and emulsion stability upon heat and freeze-thaw treatments were similar and more stable in Geerts et al. (2017) case. Pelgrom, Boom, and Schutyser (2014) established that upon heat-induced gelatinization, gel firmness was mainly increased by the presence of starch, while the presence of dispersed components (protein and/or fibre patches) in the gel weakened its structure.

Bessada, Barreira, \& Oliveira (2019) concluded that despite the highlighted advantages, exploring peas (besides other pulses) as protein sources, issues with selecting most optimal production and processing technologies to improve their rheological and sensorial properties still need to be addressed.

Lu, Donner and Liu (2018) applied roasting and alginate encapsulation of pea starch fraction with the aim to enhance the amount of slowly digestible starch and resistant starch in the processed pea products, because most part of isolated pea starch after gelation becomes rapidly digestible starch. 


\section{Pea in meat products' analogues}

Individual pea fractions (protein, starch and fibre) have been used as functional ingredients in analogue meat products: textured pea protein for formation of analogue 'fibrous' texture with neutral taste, pea starch as a binder to ensure binding properties of meat proteins and pea fibre as texture modifying agents best to mimic meaty texture (Bedin et al., 2018; Pietrasik et al., 2020).

Above described pea protein properties and possible modifications to enhance their functional properties, including good capacity in fat/ water binding, allowing adequate texture, emulsification, and gelation, have been employed in development and production of plant based meat alternatives (listed in Table 2). Pietrasik et al., (2020) established that pea starch and fibre can be utilized as gluten free alternatives to wheat crumb for meat binder applications without impact on consumer acceptability.

Bedin et al. (2018) saw that most challenging task when developing new vegan foods is to find the most suitable recipe for vegans accepted meat products analogues. One should cope with the consumer's preferences on one side and take into consideration issues of product's expected texture and shelf life, on the other hand (Bedin et al., 2018). In their case, product recipes with $80-92 \%$ of pea textured proteins provided ready product with very compact, rigid consistency, which could easily break or be extremely fibrous. Adding of gluten proteins to the recipe with pea textured proteins as a base resulted in ready product with consistency and texture analogous to the original products (Bedin et al., 2018). But most successful recipes in terms of preserving the elasticity, typical of the traditional meat-based products for two traditional Italian meat product alternatives were acquired when solely wheat proteins were used (17.0 23.4\%) (Bedin et al., 2018).

Pea protein in dairy products' alternatives

Emulsifying properties of food oil-in-water systems of pea proteins and protein isolates are directly related to protein structure, molecular weight, conformational stability, amino acid composition (charged or neutral, polar or non-polar), water solubility, and surface hydro-phobicity (or -philicity), as well as temperature, $\mathrm{pH}$, or ionic strength (Bessada, Barreira, \& Oliveira, 2019).

Pea protein nutritional and functional properties and ability of its fractions to form soft gels (analogue to whey protein) could be employed in the development and production of dairy analogues - drinks, fermented products, curd. Solubility is an important property for functional ingredients in high moisture foods, such as emulsions, foams, and beverages. Pea protein isolate's (PPI) lower solubility and chalky mouth-feel in protein beverages are determined by high amount of salt-soluble globulin with a predominant $\beta$-sheet structure (Carbonaro, Maselli, \& Nucara, 2015; Lan et al., 2019). Lan et al. (2019) established that with solid dispersion-based spray-drying processing PPI's functional properties (especially water solubility) were improved, and they were strongly affected by the type and ratio (to PPI) of added amorphous matrix carrier (gum arabic or maltodextrin). Additionally, the use of amorphous matrix carrier (gum arabic and maltodextrin) assisted in unfolding of PPI's secondary structure, which decreased contents of beany flavour markers (1-pentanol and 1- octen-3-ol); however, accelerated lipid oxidation (producing off-flavour compounds) could still occur during high temperature spray-drying (Lan et al., 2019). Zha et al. (2019) observed that emulsifying properties and flavour profile of pea protein concentrate (PPC) conjugated with gum arabic (polysaccharide) through Maillard reaction were enhanced; thus, it could promote the utilization of pea proteins as functional ingredients in food industry.

Yousseef et al. (2016) observed that the partial substitution of milk protein with pea protein did not enhance the physico-chemical characteristics of fermented dairy gels studied and dramatically reduced the quality of products regarding their texture and flavour profiles (Yousseef et al., 2016). The intensity of negative sensory profile's descriptors (earth, smoked, pea, acid and fluid) increased with enhanced pea protein ratio.

Ben-Harb et al. (2020) established that microbial consortia can efficiently reduce off-notes (majorly decreased concentrations of 'green aldehydes') and increase volatile aroma compounds in gels enriched with pea proteins. They proposed that fermentation could be successfully applied to develop plantbased protein food products with diversified sensory characteristics, and the composition of the gel essentially dictates metabolic activity and growth of the microbial community (Ben-Harb et al., 2020).

Plant-based cheese from corn and tapioca starches, vegetable oils and PPI showed no functional applicability in the creation of plant-based cheeses lacking desired melting behaviour and other sensory properties when compared to Cheddar cheese (Mattice \& Marangoni, 2020).

\section{Conclusions}

Field pea chemical composition directly indicates what kind of nutritional and health benefits are gained when consuming whole pea or its fractions, and there is vast scientific data to confirm that. Pea protein, starch and fibre have demonstrated functional properties in different food systems, including - emulsification, oilin-water system stabilisation, texture modification, binding, gelation, foaming and solubility. Mostly 
pea protein ingredients (isolates, concentrates) have been used in commercially available novel vegan foods as a source of protein. Pea protein functional properties and degree of purity depend on methods used to extract/fractionate specific pea protein ingredient and food system where it is intended to be used. It is functionally possible and nutritionally, and ecologically desirable to develop novel vegan foods intended as animal product alternatives with acceptable sensory properties.

\section{References}

Bansal, P., \& Bansal, V. (2019). Dry Pea: Production Driven by Demand for Animal Feed. In D. K. Navarro \& V. Rawal (Eds.), The Global Economy of Pulses, $1^{\text {st }}$ ed. (pp. 99-106). Rome: FAO.

Bedin, E., Torricelli, C., Gigliano, S., De Leo, R., \& Pulvirenti, A. (2018). Vegan foods: Mimic meat products in the Italian market. International Journal of Gastronomy and Food Science, 13, 1-9. DOI: 10.1016/j. ijgfs.2018.04.003.

Beitane, I., \& Krumina-Zemture, G. (2017). Dietary micronutrient content in pea (Pisum Sativum L.) and buckwheat (Fagopyrum Esculentum M.) flour. In E. Straumite (Ed.), $11^{\text {th }}$ Baltic Conference on Food Science and Technology 'Food science and technology in a changing world' (Vol. 700, pp. 56-60). DOI: 10.22616/foodbalt.2017.007.

Ben-Harb, S., Irlinger, F., Saint-Eve, A., Panouillé, M., Souchon, I., \& Bonnarme, P. (2020). Versatility of microbial consortia and sensory properties induced by the composition of different milk and pea proteinbased gels. LWT-Food Science and Technology, 118, 21. DOI: 10.1016/j.lwt.2019.108720.

Bessada, S.M.F., Barreira, J.C.M., \& Oliveira, M.B.P.P. (2019). Pulses and food security: Dietary protein, digestibility, bioactive and functional properties. Trends in Food Science and Technology, 93(228), 53-68. DOI: $10.1016 /$ j.tifs.2019.08.022.

Boye, J., Zare, F., \& Pletch, A. (2010). Pulse proteins: Processing, characterization, functional properties and applications in food and feed. Food Research International, 43(2), 414-431. DOI: 10.1016/j. foodres.2009.09.003.

Carbonaro, M., Maselli, P., \& Nucara, A. (2015). Structural aspects of legume proteins and nutraceutical properties. Food Research International, 76(P1), 19-30. DOI: 10.1016/j.foodres.2014.11.007.

Cheng, M., Qi, J.R., Feng, J.L., Cao, J., Wang, J.M., \& Yang, X.Q. (2018). Pea soluble polysaccharides obtained from two enzyme-assisted extraction methods and their application as acidified milk drinks stabilizers. Food Research International, 109, 544-551. DOI: 10.1016/j.foodres.2018.04.056.

Dahl, W.J., Foster, L.M., \& Tyler, R.T. (2012). Review of the health benefits of peas (Pisum sativum L.). British Journal of Nutrition, 108 (Suppl. 1). DOI: 10.1017/S0007114512000852.

De Almeida Costa, G.E., Da Silva Queiroz-Monici, K., Pissini Machado Reis, S.M., \& De Oliveira, A.C. (2006). Chemical composition, dietary fibre and resistant starch contents of raw and cooked pea, common bean, chickpea and lentil legumes. Food Chemistry, 94(3), 327-330. DOI: 10.1016/j.foodchem.2004.11.020.

FAOSTAT. (2020). FAOSTAT. Retrieved February 6, 2020, from http://www.fao.org/faostat/en/\#data/QC/ visualize.

Geerts, M.E.J., Mienis, E., Nikiforidis, C.V., van der Padt, A., \& van der Goot, A.J. (2017). Mildly refined fractions of yellow peas show rich behaviour in thickened oil-in-water emulsions. Innovative Food Science and Emerging Technologies, 41, 251-258. DOI: 10.1016/j.ifset.2017.03.009.

Hoover, R., Hughes, T., Chung, H.J., \& Liu, Q. (2010). Composition, molecular structure, properties, and modification of pulse starches: A review. Food Research International, 43(2), 399-413. DOI: 10.1016/j. foodres.2009.09.001.

Kalogeropoulos, N., Chiou, A., Ioannou, M., Karathanos, V.T., Hassapidou, M., \& Andrikopoulos, N.K. (2010). Nutritional evaluation and bioactive microconstituents (phytosterols, tocopherols, polyphenols, triterpenic acids) in cooked dry legumes usually consumed in the Mediterranean countries. Food Chemistry, 121(3), 682-690. DOI: 10.1016/j.foodchem.2010.01.005.

Kirse, A., \& Karklina, D. (2014). Attitudes of Latvian adults to the consumption of pulses. In Research for Rural Development, 21-23 May 2014, (pp. 130-137). Jelgava: Latvia University of Agriculture.

Krumina-Zemture, G., Beitane, I., \& Gramatina, I. (2016). Amino acid and dietary fibre content of pea and buckwheat flours. In Research for Rural Development, 18-20 May 2016, (pp. 84-90). Jelgava: Latvia University of Agriculture.

Lan, Y., Xu, M., Ohm, J. B., Chen, B., \& Rao, J. (2019). Solid dispersion-based spray-drying improves solubility and mitigates beany flavour of pea protein isolate. Food Chemistry, 278, 665-673. DOI: 10.1016/j. foodchem.2018.11.074. 
Lu, Z.-H., Donner, E., \& Liu, Q. (2018). Effect of roasted pea flour/starch and encapsulated pea starch incorporation on the in vitro starch digestibility of pea breads. Food Chemistry, 245(Supplement C), 7178. DOI: 10.1016/j.foodchem.2017.10.037.

Mattice, K.D., \& Marangoni, A.G. (2020). Physical properties of plant-based cheese products produced with zein. Food Hydrocolloids, 105, 105746. DOI: 10.1016/j.foodhyd.2020.105746.

Messina, M., \& Venter, C. (2020). Recent Surveys on Food Allergy Prevalence. Nutrition Today, 55(1), $22-29$. DOI: $10.1097 /$ nt.0000000000000389.

Michaels, T.E. (2015). Grain Legumes and Their Dietary Impact: Overview. In the World of Food Grains (Vol. 1-4, pp. 265-273). Elsevier Inc DOI: 10.1016/B978-0-12-394437-5.00040-1.

Moreno, H.M., Domínguez-Timón, F., Díaz, M.T., Pedrosa, M.M., Borderías, A.J., \& Tovar, C.A. (2020). Evaluation of gels made with different commercial pea protein isolate: Rheological, structural and functional properties. Food Hydrocolloids, 99, 105375. DOI: 10.1016/j.foodhyd.2019.105375.

Osmane, B., Konosonoka, I. H., Proskina, L., \& Cerina, S. (2016). Chemical composition of various pea and bean varieties grown in Latvia. In Engineering for Rural Development, 25-27 May 2016, (pp. 262-267). Jelgava: Latvia University of Agriculture.

Pelgrom, P.J.M., Boom, R.M., \& Schutyser, M.A.I. (2014). Functional analysis of mildly refined fractions from yellow pea. Food Hydrocolloids, 44, 12-22. DOI: 10.1016/j.foodhyd.2014.09.001.

Pietrasik, Z., Sigvaldson, M., Soladoye, O.P., \& Gaudette, N.J. (2020). Utilization of pea starch and fibre fractions for replacement of wheat crumb in beef burgers. Meat Science, 161(October 2019), 107974. DOI: $10.1016 /$ j.meatsci.2019.107974.

Rawal, V., Charrondiere, R., Maria, X., \& Fernanda, G. (2019). Pulses: Nutritional Benefits and Consumption Patterns. In V. Rawal \& D. K. Navarro (Eds.), The Global Economy of Pulses $1^{\text {st }}$ ed., pp. 9-19). Rome: FAO.

Regulation No 1308/2013 of the European Parliament and of the Council (2013). Retrieved February 6, 2020, from https://eur-lex.europa.eu/legal-content/EN/TXT/PDF/?uri=CELEX:02013R1308-20190101\&qid=1 $583485376550 \&$ from $=$ LV.

Rohn, S., \& van Griensven, L. (2015). Grain legumes and further gluten free legumes-Science, technology and impacts on human health. Food Research International, 76, 1-2. DOI: 10.1016/j.foodres.2015.03.010.

Roy, F., Boye, J.I., \& Simpson, B.K. (2010). Bioactive proteins and peptides in pulse crops: Pea, chickpea and lentil. Food Research International, 43(2), 432-442. DOI: 10.1016/j.foodres.2009.09.002.

Shand, P.J., Ya, H., Pietrasik, Z., \& Wanasundara, P.K.J.P.D. (2007). Physicochemical and textural properties of heat-induced pea protein isolate gels. Food Chemistry, 102(4), 1119-1130. DOI: 10.1016/j. foodchem.2006.06.060.

Singh, B., Singh, J.P., Kaur, A., \& Singh, N. (2017). Phenolic composition and antioxidant potential of grain legume seeds: A review. Food Research International, 101(June), 1-16. DOI: 10.1016/j.foodres.2017.09.026.

Sun, X.D., \& Arntfield, S.D. (2011). Gelation properties of salt-extracted pea protein isolate induced by heat treatment: Effect of heating and cooling rate. Food Chemistry, 124(3), 1011-1016. DOI: 10.1016/j. foodchem.2010.07.063.

Tayeh, N., Aubert, G., Pilet-Nayel, M.L., Lejeune-Hénaut, I., Warkentin, T.D., \& Burstin, J. (2015). Genomic tools in pea breeding programs: Status and perspectives. Frontiers in Plant Science, 6(November), 1-13. DOI: $10.3389 /$ fpls.2015.01037.

Van Dooren, C., Marinussen, M., Blonk, H., Aiking, H., \& Vellinga, P. (2014). Exploring dietary guidelines based on ecological and nutritional values: A comparison of six dietary patterns. Food Policy, 44, 36-46. DOI: 10.1016/j.foodpol.2013.11.002.

Yang, H., Guérin-Deremaux, L., Zhou, L., Fratus, A., Wils, D., Zhang, C., ...Miller, L.E. (2012). Evaluation of nutritional quality of a novel pea protein. Agro Food Industry Hi-Tech, 23(6), 8-10.

Yousseef, M., Lafarge, C., Valentin, D., Lubbers, S., \& Husson, F. (2016). Fermentation of cow milk and/or pea milk mixtures by different starter cultures: Physico-chemical and sensorial properties. LWT-Food Science and Technology, 69, 430-437. DOI: 10.1016/j.lwt.2016.01.060.

Zha, F., Dong, S., Rao, J., \& Chen, B. (2019). The structural modification of pea protein concentrate with gum Arabic by controlled Maillard reaction enhances its functional properties and flavor attributes. Food Hydrocolloids, 92, 30-40. DOI: 10.1016/j.foodhyd.2019.01.046. 